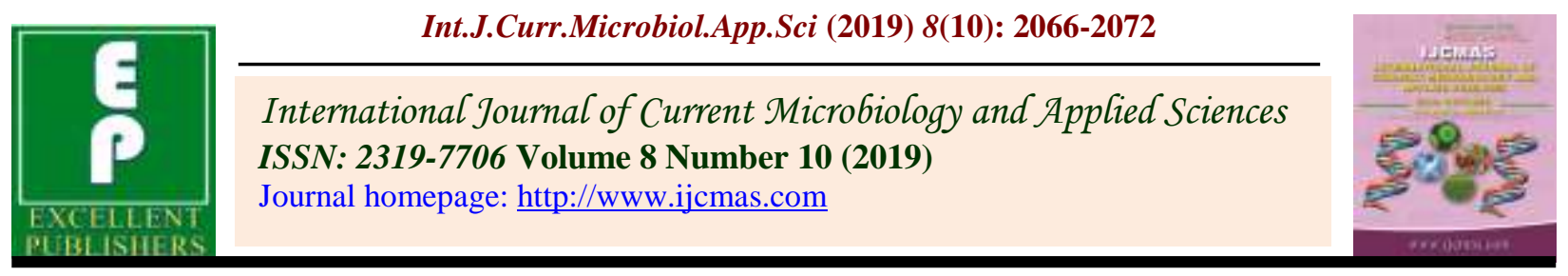

Original Research Article

https://doi.org/10.20546/ijcmas.2019.810.240

\title{
Enhancing the Performance of Basmati Rice (Oryza sativa L.) through Fly Ash and Nitrogen Management
}

\author{
Gurpreet Singh and Balwinder Singh Dhillon* \\ College of Agriculture, Guru Kashi University, Talwandi Sabo, Punjab, India \\ *Corresponding author
}

\begin{tabular}{|l|}
\hline Ke y w o r d s \\
Basmati rice, Fly \\
ash, Grain yield, \\
Growth and \\
nitrogen
\end{tabular}

\section{A B S T R A C T}

\section{Introduction}

Basmati rice known as "Queen of Rice" (bas means aroma, mati means queen), occupies a special status in developing countries. It has great export potential due to its aroma, sweet taste, dry and soft texture and excellent cooking qualities (Sidhu et al., 2004). Rice is highly nutritive crop and contains carbohydrate, protein, fat, minerals (phosphorus, calcium, iron etc.) and amino acids.

Fly ash is produced as a result of coal combustion in thermal power station and discharged in ash ponds. In India and most countries major source of electrical energy is coal based thermal power plants, which produces 175 million tonnes. Disposal of high amount of fly ash from thermal power plants absorbs huge amount of water, energy and land area by ash ponds. The fly ash utilization in the country is estimated to be about 59\% only (Kanungo, 2013) Therefore fly ash management would remain a great concern of the century. However, several studies purposed that fly ash can be used as a soil ameliorant that may improve physical, chemical, biological properties of the soil and is a source of readily available plant micro and 
macro-nutrients. Addition of small amounts of fly ash to soil neutralizes the acidity to a level suitable for agriculture. Application of fly ash increased the yield in various crops with improvement in the physical, chemical and biological properties and found beneficial for soil and crop (Kohli et al., 2010). Nitrogen is an essential constituent of proteins, chlorophyll and metabolites such as alkaloids, nucleotides, phosphatides, enzymes, vitamins and hormones etc. which have great importance in plant metabolism.

Nitrogen increase crop yield and protein content in grains. It also promotes the vegetative growth in rice. Nitrogen play a key role in plant physiological processes influenced the sink size thereby increasing the grain yield of rice (Somasundaram et al., 2002). Application of nitrogen fertilizer to the basmati rice, leads to increase the plant height, leaf size, number of panicle, number of spikelet and grain yield (Balasubramanian 2002; Walker et al., 2008). Nitrogen is an important component of rice production technology with high yielding cultivars and its important role in increasing rice productivity (Kumar and Prasad, 2004). Keeping in view the present study was planned to study the effect of different levels of fly ash and nitrogen on the performance of basmati rice.

\section{Materials and Methods}

The present investigation Enhancing the performance of basmati rice (Oryza sativa L.) through fly ash and nitrogen management was conducted at Research Farm, University College of Agriculture, Guru Kashi University, Talwandi Sabo, Bathinda during kharif season of 2018. Talwandi Sabo is located at $29^{\circ} 57 \mathrm{~N}$ latitude and $75^{\circ} 7 \mathrm{E}$ longitudes and altitudes $(213 \mathrm{~m}$ above sea levels). The tract is characterized by semi-arid climate. Maximum temperature is about 45$47^{\circ} \mathrm{C}$ is not uncommon during summer, while freezing temperature accompanied by frost occurrence may be witnessed in the month of December and January. The mean annual rainfall fluctuates around $150 \mathrm{~mm}$, major part of which is during the month of July to November. The soil of experimental field was slightly alkaline ( $\mathrm{pH}$ 7.8) with normal electrical conductivity $\left(1.41 \mathrm{dSm}^{-1}\right)$, low in organic carbon content $(0.29 \%)$ and available nitrogen $\left(233.7 \mathrm{~kg} \mathrm{ha}^{-1}\right)$, medium in available phosphorus $\left(15.0 \mathrm{~kg} \mathrm{ha}^{-1}\right)$ and available potassium $\left(216.8 \mathrm{~kg} \mathrm{ha}^{-1}\right)$. The experiment was laid out in split plot design with three replications. The treatment comprising of three levels of viz., control, fly ash @ $10 \mathrm{t} \mathrm{ha}^{-1}$, fly ash@20 t ha ${ }^{-1}$ and four levels of nitrogen viz., $40 \mathrm{~kg} \mathrm{~N} \mathrm{ha}^{-1}, 50 \mathrm{~kg} \mathrm{~N} \mathrm{ha}^{-1}, 60 \mathrm{~kg} \mathrm{~N}^{-1}$ and $70 \mathrm{~kg} \mathrm{~N} \mathrm{ha}^{-1}$.

The plant height, number of tillers and number of effective tillers was counted manually from randomly selected five plants at maturity in each plot. The panicle length from base of plant to tip of panicle from the five randomly selected plants in each plot was measured and average value was expressed in centimeters. The dry matter accumulation was recorded from each selected plants from each plot firstly sun dried and then kept it in oven for 24 hrs at $65^{\circ} \mathrm{C}$ then weighing and expressed it in $\mathrm{q} \mathrm{ha}{ }^{-1}$. The weight of total produce per plot was recorded after harvest of the crop with the help of spring balance. The bundle weight was taken before threshing and plot wise straw yield was obtained after deducting the grain weight from the whole bundle weight. The weight of randomly 1000-grains was recorded from each plot and expressed in $\mathrm{g}$. The harvest index was calculated by using following formula:

Harvest Index $(\%)=\frac{\text { Grain yield }}{\text { Biological yield }} \times 100$

Fisher's ANOVA technique and least 
significant difference (LSD) test at 5\% probability level was used to compare differences among treatment means (Steel and Torrie, 1981).

\section{Results and Discussion}

\section{Growth parameters of basmati rice}

Amongst the fly ash levels, highest plant height $(117.4 \mathrm{~cm})$ was recorded with the application of fly ash @ 20t ha ${ }^{-1}$ which was significantly higher than other treatments (Table 1). Amongst the nitrogen levels, highest plant height $(116.8 \mathrm{~cm})$ was recorded with the application of nitrogen $70 \mathrm{~kg} \mathrm{~N} \mathrm{ha}^{-1}$ which was significantly higher than other treatments. The lowest plant height was recorded with the application of $40 \mathrm{~kg} \mathrm{~N} \mathrm{ha}^{-1}$. Similar results were also reported by Reddy et al., (2010) and Singh et al., (2007)

Significantly higher number of total tillers $\mathrm{m}^{-1}$ row length (82.5) was recorded with the application of fly ash @ 20t ha ${ }^{-1}$ which was significantly higher than other treatments, whereas the lowest number of total tillers $\mathrm{m}^{-1}$ of row length (68.5) were recorded in control (Table 1). Amongst the nitrogen levels, the maximum number of tillers $\mathrm{m}^{-1}$ of row length (79.6) was recorded with the application of 70 $\mathrm{kg} \mathrm{N} \mathrm{ha}{ }^{-1}$. Similar results were also reported by Mittra et al., (2005) and Sikdar et al., (2006).

Significantly higher dry matter accumulation (143.3 q ha ${ }^{-1}$ ) was recorded with the application of fly ash @ 20t ha ${ }^{-1}$ which was significantly higher than other treatments (Table 1). The lowest dry matter accumulation (104.8 $\left.\mathrm{q} \mathrm{ha}^{-1}\right)$ was recorded in $20 \mathrm{t}$ fly ash ha and $70 \mathrm{~kg} \mathrm{~N} \mathrm{ha}{ }^{-1}$. The nitrogen application @ $70 \mathrm{~kg} \mathrm{ha}^{-1}$ resulted in higher number of tillers $\mathrm{m}^{-1}$ of row length (137.6). Similar results were also reported by Deshmukh et al., (2000) and Mannan et al., (2010).

\section{Yield attributes of basmati rice}

The application of fly ash@20 t ha ${ }^{-1}$ with 70 $\mathrm{kg} \mathrm{N} \mathrm{ha-1}$ recorded maximum number of effective tillers/m of row length (78.5) of basmati rice, which was significantly higher over all the treatments (Table 2). The lowest number of effective tiller/m of row length was recorded in treatment receiving no fly ash. Amongst the nitrogen levels the maximum number of effective tillers/m of row length (74.6) was recorded with the application of 70 $\mathrm{kg} \mathrm{N} / \mathrm{ha}^{-1}$. Similar results were also reported by Das et al., (2013) and Sikdar et al., (2006).

Maximum panicle length (27.1) of basmati rice was recorded in fly ash @ 20t ha ${ }^{-1}$ which was significantly higher than control and fly ash@10 $\mathrm{t} \mathrm{ha}^{-1}$ (Table 2). Whereas, the minimum panicle length $(24.8 \mathrm{~cm})$ was recorded in control. The different levels of nitrogen influenced the panicle length of rice, Out of different levels of $\mathrm{N}$, maximum panicle length $(26.3 \mathrm{~cm})$ observed in $70 \mathrm{~kg} \mathrm{~N} \mathrm{ha}{ }^{-1}$, which was significantly higher than other $\mathrm{N}$ levels. The minimum panicle length $(24.7 \mathrm{~cm})$ was recorded in $40 \mathrm{~kg} \mathrm{~N}^{-1}$. Similar result were also reported by Karmakar et al., (2010) and Bhattacharya and Singh (1991).

Amongst the different levels of fly ash, the highest number of grains panicle ${ }^{-1}$ (104.3) of basmati rice was recorded in fly ash @ $20 \mathrm{tha}^{-}$ ${ }^{1}$, which was significantly higher than control and fly ash @ 10t ha ${ }^{-1}$. The lowest number of grains panicle ${ }^{-1}(86.3)$ was recorded in control. The nitrogen levels also significantly increase the number of grains panicle ${ }^{-1}$ of basmati rice. It was observed that the highest mean number of grains/panicle (100.4) was recorded in 60 $\mathrm{kg} \mathrm{N} \mathrm{ha}{ }^{-1}$, which was significantly higher than other $\mathrm{N}$ levels. The lowest number of grains panicle $^{-1}$ (88.1) was recorded in $40 \mathrm{~kg} \mathrm{~N} \mathrm{ha}^{-1}$. Similar results were also reported by Das et al., (2013) and Mannan et al., (2010). 
Table.1 Growth parameters of basmati rice as influenced by different fly ash and nitrogen levels

\begin{tabular}{|c|c|c|c|}
\hline Treatment & $\begin{array}{l}\text { Plant height } \\
\text { (cm) }\end{array}$ & $\begin{array}{l}\text { Number of tillers } \mathrm{m}^{-1} \\
\text { row length }\end{array}$ & $\begin{array}{c}\text { Dry matter } \\
\text { accumulation }\left(\mathbf{q} \mathbf{h a}^{-1}\right)\end{array}$ \\
\hline \multicolumn{4}{|c|}{ Fly ash levels $\left(\mathrm{t} \mathrm{ha}^{-1}\right)$} \\
\hline Control & 112.5 & 68.5 & 104.8 \\
\hline 10 & 115.5 & 72.2 & 123.4 \\
\hline 20 & 117.4 & 82.8 & 143.3 \\
\hline LSD $(P=0.05)$ & 0.1 & 0.9 & 1.06 \\
\hline \multicolumn{4}{|c|}{ Nitrogen levels $\left(\mathrm{kg} \mathrm{ha}^{-1}\right)$} \\
\hline 40 & 113.3 & 68.1 & 109.1 \\
\hline 50 & 114.7 & 73.5 & 119.7 \\
\hline 60 & 115.6 & 76.8 & 128.8 \\
\hline 70 & 116.8 & 79.6 & 137.6 \\
\hline LSD $(P=0.05)$ & 0.1 & 0.8 & 0.9 \\
\hline
\end{tabular}

Table. 2 Yield attributing characters of basmati rice as influenced by different fly ash and nitrogen levels

\begin{tabular}{|c|c|c|c|c|}
\hline Fly ash & $\begin{array}{l}\text { No. of effective tillers } \\
\mathbf{m}^{-1} \text { of row length }\end{array}$ & $\begin{array}{c}\text { Panicle length } \\
(\mathrm{cm})\end{array}$ & $\begin{array}{c}\text { Number of grains } \\
\text { panicle }^{-1}\end{array}$ & $\begin{array}{l}\text { Test weight } \\
\text { (g) }\end{array}$ \\
\hline \multicolumn{5}{|c|}{ Fly ash levels $\left(\mathrm{t} \mathrm{ha}^{-1}\right)$} \\
\hline Control & 63.1 & 24.8 & 86.3 & 20.8 \\
\hline 10 & 67.3 & 25.1 & 92.8 & 21.1 \\
\hline 20 & 78.5 & 27.1 & 104.3 & 20.9 \\
\hline LSD $(P=0.05)$ & 0.9 & 0.2 & 0.8 & NS \\
\hline \multicolumn{5}{|c|}{ Nitrogen levels $\left(\mathrm{kg} \mathrm{ha}^{-1}\right)$} \\
\hline 40 & 63 & 24.7 & 88.1 & 20.6 \\
\hline 50 & 68.3 & 25.4 & 91.7 & 20.7 \\
\hline 60 & 72.7 & 26.1 & 100.4 & 21.3 \\
\hline 70 & 74.6 & 26.3 & 97.8 & 20.9 \\
\hline LSD $(\mathbf{P}=0.05)$ & 0.1 & 0.1 & 0.9 & 0.3 \\
\hline
\end{tabular}

Table.3 Grain yield of rice as influenced by different levels of fly ash and nitrogen

\begin{tabular}{|c|c|c|c|c|c|}
\hline \multirow{3}{*}{$\begin{array}{c}\text { Fly ash } \\
\text { levels } \\
\left(\mathrm{t} \mathrm{ha}^{-1}\right)\end{array}$} & \multicolumn{5}{|c|}{ Grain yield (q/ha) } \\
\hline & \multicolumn{4}{|c|}{ Nitrogen levels $\left(\mathrm{kg} \mathrm{ha}^{-1}\right)$} & \multirow[t]{2}{*}{ Mean } \\
\hline & 40 & 50 & 60 & 70 & \\
\hline Control & 39.4 & 41.7 & 42.7 & 43.5 & 41.8 \\
\hline 10 & 40.5 & 42.9 & 45.2 & 46.8 & 43.8 \\
\hline 20 & 43.7 & 46.9 & 48.5 & 49.3 & 47.1 \\
\hline Mean & 41.2 & 43.8 & 45.4 & 46.5 & 44.2 \\
\hline \multirow[t]{2}{*}{ LSD $(P=0.05)$} & \multicolumn{2}{|c|}{ Fly ash } & Vitroge & \multicolumn{2}{|c|}{ Interaction } \\
\hline & \multicolumn{2}{|c|}{0.3} & 0.5 & \multicolumn{2}{|c|}{0.9} \\
\hline
\end{tabular}


Table.4 Productivity of basmati rice as influenced by different fly ash and nitrogen levels

\begin{tabular}{|c|c|c|c|}
\hline Treatment & $\begin{array}{l}\text { Straw yield } \\
\left(\mathbf{q} \mathbf{h a}^{-1}\right)\end{array}$ & $\begin{array}{c}\text { Biological yield } \\
\left(\mathrm{q} \text { ha }^{-1}\right)\end{array}$ & $\begin{array}{c}\text { Harvest index } \\
(\%)\end{array}$ \\
\hline \multicolumn{4}{|c|}{ Fly ash levels $\left(t^{h a-1}\right)$} \\
\hline Control & 70.0 & 111.8 & 37.3 \\
\hline 10 & 74.4 & 118.3 & 37.0 \\
\hline 20 & 89.4 & 136.2 & 34.3 \\
\hline $\operatorname{LSD}(\mathbf{P}=\mathbf{0 . 0 5})$ & 1.1 & 1.4 & 0.7 \\
\hline \multicolumn{4}{|c|}{ Nitrogen levels $\left(\mathrm{kg} \mathrm{ha}^{-1}\right)$} \\
\hline 40 & 73.6 & 114.8 & 35.9 \\
\hline 50 & 76.5 & 120.3 & 36.4 \\
\hline 60 & 79.3 & 124.8 & 36.5 \\
\hline 70 & 82.4 & 128.9 & 36.1 \\
\hline LSD (P=0.05) & 1.1 & 1.0 & 0.6 \\
\hline
\end{tabular}

Test weight of basmati rice does not differed significantly amongst fly ash levels (Table 2). The effect of the increasing fly ash levels on test weight was found be not significant. Amongst the different nitrogen levels, more 1000 -grain weight $(21.3 \mathrm{~g})$ obtained in $60 \mathrm{~kg}$ $\mathrm{N}^{-1} \mathrm{a}^{-1}$, which was significantly higher over the other levels of nitrogen. The lowest 1000 grain weight $(20.6 \mathrm{~g})$ was obtained in $40 \mathrm{~kg} \mathrm{~N}$ $\mathrm{ha}^{-1}$. Similar results were also reported by Singh et al., (2011).

\section{Productivity of basmati rice}

The interaction effects on grain yield of rice were found to be significant (Table 3). Fly ash @ $20 \mathrm{ha}^{-1}$ recorded highest grain yield $(49.3 \mathrm{q}$ $\mathrm{ha}^{-1}$ ) under $70 \mathrm{~kg} \mathrm{~N} \mathrm{ha}{ }^{-1}$, which was statistically at par with fly ash @ $20 \mathrm{tha}^{-1}$ and $60 \mathrm{~kg} \mathrm{~N} \mathrm{ha}^{-1}$ and minimum grain yield $(39.4 \mathrm{q}$ $\mathrm{ha}^{-1}$ ) was recorded in control (no fly ash) and $40 \mathrm{~kg} \mathrm{~N} \mathrm{ha}^{-1}$.

The highest straw yield $\left(89.1 \mathrm{q} \mathrm{ha}^{-1}\right)$ of basmati rice was observed with the application of fly ash @ $20 \mathrm{t} \mathrm{ha}^{-1}$, which was significantly higher than control and fly ash @ $10 \mathrm{t} \mathrm{ha}^{-1}$ (Table 4). The lowest straw yield $\left(70.0 \mathrm{q} \mathrm{ha}^{-1}\right)$ of basmati rice was recorded in control. The different levels of $\mathrm{N}$ also increased the straw yield of basmati rice. The highest straw yield $\left(82.4 \mathrm{q} \mathrm{ha}^{-1}\right)$ was observed in $70 \mathrm{~kg} \mathrm{~N} \mathrm{ha}{ }^{-1}$, which was significantly higher than other levels of $\mathrm{N}$. The lowest straw yield (73.6 q ha $\left.{ }^{-1}\right)$ was recorded in 40 $\mathrm{kg} \mathrm{N} \mathrm{ha}{ }^{-1}$. This finding was in conformity with that of Reddy et al., (2010) and Islam et al., (2008).

The highest biological yield (136.2 $\left.\mathrm{q} \mathrm{ha}^{-1}\right)$ was recorded in fly ash @ 20t ha ${ }^{-1}$ ) which was significantly higher than control and fly ash @ $10 \mathrm{t} \mathrm{ha}^{-1}$ (Table 4). The lowest biological yield $\left(105.6 \mathrm{q} \mathrm{ha}^{-1}\right)$ was recorded in control. The different $\mathrm{N}$ levels also increased the biological yield of rice. Amongst the different $\mathrm{N}$ levels the highest biological yield (128.9 q $\mathrm{ha}^{-1}$ ) was recorded in $70 \mathrm{~kg} \mathrm{~N}^{-1}$ ) which was significantly differed than other levels of $\mathrm{N}$. The lowest yield (114.8 q ha ${ }^{-1}$ ) was recorded in $40 \mathrm{~kg} \mathrm{~N} \mathrm{ha}^{-1}$.

Amongst the fly ash levels, the maximum harvest index (37.3\%) was observed in control which significantly higher than fly ash @ $10 \mathrm{t} \mathrm{ha}^{-1}$ and fly ash @ $20 \mathrm{tha}^{-1}$. The lowest harvest index (34.3\%) was recorded in fly ash @ $20 \mathrm{tha}^{-1}$. The $\mathrm{N}$ levels also influenced the harvest index percentage. The highest harvest index $(36.1 \%)$ was recorded in $60 \mathrm{~kg} \mathrm{~N} \mathrm{ha}^{-1}$ 
which significantly higher over other $\mathrm{N}$ levels. The lowest harvest index $(35.9 \%)$ was recorded in $40 \mathrm{~kg} \mathrm{~N} \mathrm{ha}^{-1}$.

In conclusion, application of fly ash @ $20 \mathrm{t}$ $\mathrm{ha}^{-1}$ resulted in maximum growth parameter, yield attributes and grain yield, which was significantly higher than control and fly ash @ 10t/ha. Among the different nitrogen levels, application of $70 \mathrm{~kg} \mathrm{~N} \mathrm{ha}{ }^{-1}$ recorded the maximum growth parameters, yield attributes and grain yield of basmati rice than the lower levels of $\mathrm{N}$. The maximum grain yield recorded with the application fly ash @ $20 \mathrm{t}$ $\mathrm{ha}^{-1}$ and $70 \mathrm{~kg} \mathrm{~N} \mathrm{ha}^{-1}$ which significantly higher but at par with fly ash @ $20 \mathrm{t} \mathrm{ha}^{-1}$ and $60 \mathrm{~kg} \mathrm{~N} \mathrm{ha}^{-1}$. The data recommended that the integration of fly ash @ $20 \mathrm{t} \mathrm{ha}^{-1}$ and $60 \mathrm{~kg} \mathrm{~N}$ $\mathrm{ha}^{-1}$ is sufficient to get optimum yield of basmati rice.

\section{References}

Anonymous (2018).Kharif crop outlook 2017/2018. Pp-24. International Rice Research Institute (2002). Rice Almanac, $3^{\text {rd }}$ Edition. (Gramene Reference ID 8379)

Balasubramanian R (2002) Response of hybrid rice (Oryza sativa L.) to levels and time of application of nitrogen. Indian Journal of Agronomy 47: 20306.

Bhattacharya H C and Singh K N (1991) Response of direct-seeded rice to level and time of nitrogen application. Indian Journal of Agronomy 37: 681-85.

Das B K, Choudhary B H, Das K N (2013) Effect of integration of fly ash with fertilizers and Farm yard manure on nutrient availability, Yield and nutrients uptake of rice in Inceptisols of Assam, India. International Journal of Advancements in Research and Technology 2: 190-208.

Deshmukh A, Matti D B and Bharti B (2000)
Soil properties as influenced by application of fly ash, Journal of Soils and Crops 10:69-71.

Islam M S, Hossain M A, Chowdhury M A H and Hannan M A (2008) Effect of nitrogen and transplanting date on yield and yield component of aromatic rice. Journal of Bangladesh Agricultural University 6:291-96.

Kanungo, S P (2013) Laboratory studies and field application of fly ash in forest nurseries and plantation at CSIRIMMT, National workshop on use of fly ash in forestry and development of degraded/wasteland, helt during September 12-13, 2013,pp 23-33.

Karmakar, S, Mittra, B N and Ghosh, B C (2010) Enriched coal ash utilization for augmenting production of rice under acid lateritic soil. Coal combustion and Gasification products 2: 45-50.

Kohali, S J and Goyal, D (2010) Effect of fly ash application on soil physical properties and microbial activities of soil. Acta Agrophysical 16(22), 327-35.

Mahaskar H V, Thorat S T, Dhagat S B (2005) Effect of nitrogen on leaf area, leaf area index and grain yield of scented rice varieties. Journal of soil and crop 5:218-20.

Mannan M A, Bhuiya M S U, Hossain H M A and Akhand M I M (2010) Optimization of nitrogen rate for aromatic basmati rice (Oriza sativa L.). Bangladesh Journal of Agriculture Research 35:157-65.

Matte, D B and Kene, D R (1995) Effect of fly ash application on yield performance of kharif and rabi crops. Journal of soils and crops 5:133-36.

Mittra, B N, Karmakar, S, Swain, D K, Ghosh, B C, (2005) Fly ash a potential source of soil amendment and a component of integrated plant nutrient supply system. Fuel 84, 1447-51.

Reddy T, Prabhakar U, Rao M, 
Chandrasekhar R. (2010) Effect of fly ash and Farm yard manure on soil properties and yield of rice grown on an inceptisols. Agricultural Science Digest 30:281-305.

Sidhu, M S, Sikka R and Singh T (2004) Perforamnce of transplanted basmati rice in different cropping systems as effected by $\mathrm{N}$ application. International Rice Research Notes 29:63-65.

Sikdar M S I, Rahman M M, Islam M S, Yeasmin M S and akhtar M M (2006) Effect of nitrogen levels on aromatic rice varieties and soil fertility status. International Journal of Sustainable Crop Productivity 3:49-54.

Singh H and Thakur R B (2007) Effect of level and scheduling of nitrogen application on yield and quality of Basmati rice. Journal of Applied bioscience 33:118-21.

Singh J (2011) Enhancing the performance of direct seeded Basmati rice (Oryza sativa L.) through seed priming and $\mathrm{N}$ management. M.Sc. Thesis, department of Agronomy, PAU, Ludhiana.

Somasundaram E, Sathiyavelu A, Velayutham (2002) Effect of nitrogen levels on growth and yield attributes of rice under sodic soil condition. Madras Agriculture Journal 89:506-08.

Steel, R G D and Torrie, J H. (1981) Principles and procedures of statistics: A biometrical approach. 2nd Edn. McGraw-Hill, Singapore.

\section{How to cite this article:}

Gurpreet Singh and Balwinder Singh Dhillon. 2019. Enhancing the Performance of Basmati Rice (Oryza sativa L.) through Fly Ash and Nitrogen Management. Int.J.Curr.Microbiol.App.Sci. 8(10): 2066-2072. doi: https://doi.org/10.20546/ijcmas.2019.810.240 